\title{
Exploring Diversity and Origins of Streptomycin-Resistant Erwinia amylovora Isolates in New York Through CRISPR Spacer Arrays
}

K. A. Tancos and K. D. Cox, Department of Plant Pathology and Plant-Microbe Biology, New York State Agricultural Experiment Station, Cornell University, Geneva 14456

\begin{abstract}
Tancos, K. A., and Cox, K. D. 2016. Exploring diversity and origins of streptomycin-resistant Erwinia amylovora isolates in New York through CRISPR spacer arrays. Plant Dis. 100:1307-1313.

Streptomycin is the most effective and widely used chemical control in the eastern United States for blossom blight of apple caused by Erwinia amylovora; however, resistance to this antibiotic has been a concern in New York since 2002. From 2011 to 2014, statewide collections of E. amylovora were conducted resulting in the isolation of streptomycinresistant (SmR) E. amylovora from several commercial orchards. Further genetic analysis of isolates was necessary to understand the origins and the diversity of these bacteria. Clustered regularly interspaced short palindromic repeat (CRISPR) spacer sequencing was employed to explore the diversity and possible origins of New York SmR E. amylovora isolates. The spacer array CR1, CR2, and CR3 regions of $27 \mathrm{SmR}$ E. amylovora isolates and 76 streptomycin-sensitive $(\mathrm{SmS})$ E. amylovora isolates were amplified and subsequently sequenced, revealing 19 distinct CRISPR spacer profiles for New York isolates. The majority of

SmR E. amylovora isolates had the same CRISPR profile as SmR E. amylovora isolates discovered in 2002 . This may infer that eradication efforts in 2002 failed and the bacterial populations continued to spread throughout the state. Several CRISPR profiles for SmR E. amylovora were identical to SmS E. amylovora collected from the same orchards, leading to the hypothesis that resistance may be developing within New York. Profiles not unique to New York were identical to many isolates from the Midwestern, eastern, and western United States, implying that streptomycin resistance may be due to the introduction of SmR E. amylovora from other regions of the United States. The increased understanding as to how SmR E. amylovora isolates are introduced, evolve, or have become established afforded by CRISPR profiling has been useful for disease management and restricting the movement of streptomycin resistance in New York.
\end{abstract}

Erwinia amylovora, the causal agent of fire blight, is a destructive plant pathogen infecting several Rosaceous species throughout the world (Vanneste 2000). This bacterium is especially damaging in apple and pear production, leading to devastating losses in the United States annually (Norelli et al. 2003). E. amylovora causes blossom blight shortly after bloom which, in turn, may lead to infection of shoots and rootstocks, termed shoot blight and rootstock blight (Vanneste 2000). Blighted tissues may become blackened, giving the burnt appearance for which the disease is named: fire blight (Sundin 2014). Because blossoms may serve as an entry point for bacteria and lead to infection of additional tissues, managing blossom blight is crucial for fire blight control (van der Zwet 1969).

Several cultural, biological, and chemical controls are recommended for fire blight management. Cultural practices include pruning of blighted and cankered limbs and avoiding late-season planting (van der Zwet et al. 2012). Biological controls may include applications of antagonistic or niche competing bacteria on blossoms at bloom (Johnson et al. 2009). Chemical controls include the use of copper, growth regulators, and antibiotic products such as oxytetracycline and streptomycin (van der Zwet et al. 2012). Of these controls, the most effective in the northeastern United States is streptomycin, an aminoglycoside antibiotic, which has been used to control fire blight in the United States since 1955 (Cox et al. 2013; McManus et al. 2002; Russo et al. 2008; Sundin and Ehret 2010).

The reliance of the apple industry on streptomycin has become a growing concern in recent years due to the development of

\section{Corresponding author: K. D. Cox; E-mail: kdc33@ cornell.edu}

*The $\boldsymbol{e}$-Xtra logo stands for "electronic extra" and indicates that two supplementary tables are published online.

Accepted for publication 29 February 2016.

http://dx.doi.org/10.1094/PDIS-01-16-0088-RE

(C) 2016 The American Phytopathological Society streptomycin-resistant (SmR) E. amylovora in the United States, although the determinants behind this resistance are well known (Moller et al. 1981). There are two determinants of streptomycin resistance known to occur in E. amylovora. The first determinant is the presence of a point mutation at codon 43 in the $r p s L$ gene, which codes for the $\mathrm{S} 12$ ribosomal protein. This point mutation confers a conformational change in the S12 protein, altering the binding site of streptomycin on the ribosome, which would normally inhibit translation of mRNA to protein within the bacterium (Chiou and Jones 1995b; McManus et al. 2002). The presence of this point mutation is most commonly found in SmR E. amylovora isolates from the western United States (Moller et al. 1981).

The second determinant of resistance is the presence of streptomycinmodifying enzymes within the bacterium. These aminoglycosidemodifying enzymes are coded for by the gene pair strA-strB (Chiou and Jones 1995a). These genes are commonly found in many epiphytic bacteria, such as Pseudomonas spp., and reside on conjugative R plasmids (Burr et al. 1988, 1993). In E. amylovora, strA-strB has been found on the plasmid RSF1010 and also within the transposable element Tn5393 on conjugative plasmids pEA34 and pEU30 or on nonconjugative plasmid pEA29 (Chiou and Jones 1993; Förster et al. 2015; McGhee and Sundin 2011; McManus and Jones 1994; Palmer et al. 1997). The strA-strB gene pair in Tn5393 on plasmid pEA29, the basis of resistance for the isolates discovered in 2002 in New York, is the most common determinant of resistance in Michigan (McGhee and Sundin 2011; McManus and Jones 1994; Russo et al. 2008). The presence of the $s t r A-s t r B$ gene pair in Tn5393 on plasmid pEA29 has only been found in SmR E. amylovora isolates from Michigan and New York (McGhee and Sundin 2011; McManus and Jones 1994; Russo et al. 2008).

The first reports of streptomycin resistance in the United States occurred in California in 1972 and shortly afterward in Washington (Coyier and Covey 1975; Miller and Schroth 1972). Currently, resistance is found in several western and Midwestern states such as Missouri and Michigan (McManus and Jones 1994). SmR E. amylovora was first reported in New York in 2002 with the discovery of two isolates (NY17.1 and NY17.2) that were recovered from fire blight 
outbreaks in two adjacent orchards in Wayne County (Russo et al. 2008). This finding prompted immediate eradication efforts (the removal of plantings) in order to prevent the spread of SmR E. amylovora to additional orchards. Subsequent fire blight sampling from the affected orchards and other orchards in Wayne County in 2004 and 2006 did not lead to the identification of SmR E. amylovora isolates, which led to the belief that eradication efforts were successful in containing the outbreak (Russo et al. 2008).

Following renewed concerns from New York growers regarding the performance of streptomycin for the management of fire blight in 2011, yearly statewide sampling from fire blight epidemics occurred to identify and characterize new SmR E. amylovora isolates. Surveys of New York apple orchards with fire blight outbreaks from 2011 to 2015 led to the identification of SmR E. amylovora isolates from orchards in six counties in western New York. The majority of these SmR E. amylovora isolates were found in orchards in Wayne County, with the remainder recovered from orchards in Monroe, Niagara, Orleans, Ontario, and Thompkins Counties. The basis of streptomycin resistance in the majority of isolates was due to the presence of the $s t r A-s t r B$ gene pair in transposon Tn5393 on plasmid EA29, while only two had a point mutation at codon 43 of the rpsL gene (Tancos et al. 2016). The fact that the majority of isolates were found in Wayne County orchards near the site of the 2002 outbreak and had an identical resistance genotypes to the 2002 isolates has caused a reconsideration of the extent of the 2002 subsequent eradication efforts. Moreover, the discovery of $\mathrm{SmR}$ E. amylovora isolates with the $\operatorname{rps} L$ point mutation, commonly found in the western United States (Chiou and Jones 1995b), but previously undocumented in New York, has raised concerns about additional introduction events in later years (Russo et al. 2008; Tancos et al. 2016).

To begin to investigate the origin of SmR E. amylovora, it is necessary to explore the diversity of isolates collected in New York compared with isolates collected in other regions worldwide. However, examining diversity within this species has been challenging due to extremely limited diversity within the E. amylovora genome (Sebaihia et al. 2010; Smits et al. 2010). Studies investigating techniques such as random amplified polymorphic DNA, pulse-field gel electrophoresis, variable number of tandem repeats analyses, ribotyping, and sequencing of housekeeping genes, such as groEL, have been used to explore diversity of E. amylovora, but have shown limitations in distinguishing strains (Jock et al. 2002; Kim and Geider 1999; McGhee and Sundin 2012; Momol et al. 1997). Another possibility for studying bacterial isolate diversity includes the use of clustered regularly interspaced short palindromic repeats (CRISPR). CRISPR are DNA repeat regions found in about $48 \%$ of all bacteria, which are separated by spacers that share identity with laterally transferred DNA, such as that of bacteriophages, and are acquired in a temporal manner (Horvath et al. 2008). The polarity of spacer acquisition in a $3^{\prime}$-to-5' manner produces a detailed account of foreign DNA elements the bacteria have come into contact with over time, thereby creating an inferred geographical record (Horvath et al. 2008; McGhee and Sundin 2012). The spacer content of CRISPR spacer arrays has recently been employed to explore strain diversity and to track human pathogenic bacteria, such as Escherichia coli, Yersinia pestis, and Salmonella enterica (Almendros et al. 2014; Barros et al. 2014; Shariat et al. 2013). This method has provided a high degree of differentiation between isolates that was previously unattainable with many bacterial pathogens. CRISPR have also been used successfully to study diversity of Erwinia amylovora isolates (McGhee and Sundin 2012; Rezzonico et al. 2011). McGhee and Sundin (2012) examined the diversity of 85 E. amylovora isolates from fire-blight-affected regions worldwide by sequencing CRISPR spacer array regions-termed CR1, CR2, and CR3 - which resulted in the differentiation of isolates on a regional scale. With such resolution, it would be possible to understand the emergence of SmR E. amylovora isolates within a region, the migration of isolates with specific antibiotic resistance determinants, and possibly strain tracking (Förster et al. 2015; McGhee and Sundin 2012; Rezzonico et al. 2011).

Given that streptomycin resistance in E. amylovora is just beginning to emerge in apple orchards within New York, there is a unique opportunity to examine the possible origin of SmR E. amylovora isolates throughout the state. In this capacity, the objective of this study was to investigate $E$. amylovora isolate diversity with CRISPR spacer array analysis as a means to establish a baseline from which to investigate the possible origin and sources of $\mathrm{SmR}$ E. amylovora, as well as explore potential for strain tracking of E. amylovora, in future fire blight epidemics.

\section{Materials and Methods}

Bacterial isolates. In all, $27 \mathrm{SmR}$ E. amylovora and 76 streptomycinsensitive (SmS) E. amylovora isolates collected from 61 commercial orchards, 16 of which contained SmR isolates, were used in this study. All isolates, with the exception of two isolates that contained the $r p s L$ point mutation, contained the strA-strB determinant for streptomycin resistance, as described by Tancos et al. (2016). Isolates with the gene pair strA-strB had these genes occurring on the transposon Tn5393 with the insertion site of 17,527 bp on plasmid pEA29. All isolates were stored as single-colony cultures in a $15 \%$ glycerol Luria-Bertani broth (Bertani 1952) at $-80^{\circ} \mathrm{C}$ before use. During experimentation, isolates were grown on Crosse-Goodman (CG) media (Crosse and Goodman $1973)$ at $28^{\circ} \mathrm{C}$, and only single colonies with a cratered appearance on CG media, characteristic of E. amylovora, were used for CRISPR spacer array analysis.

DNA amplification and sequencing of CRISPR spacer array regions. Single colonies were placed into $200 \mu \mathrm{l}$ of sterile $\mathrm{H}_{2} \mathrm{O}$ and vortexed for $1 \mathrm{~min}$. The resulting mixture was used as a template for colony polymerase chain reaction (PCR) amplification. PCR assays, $50 \mu \mathrm{l}$ in volume, contained $10 \mu \mathrm{l}$ of $5 \times$ GoTaq Buffer (Promega Corp., Madison, WI), $3 \mu$ l of $25 \mathrm{mM} \mathrm{MgCl}_{2}$ (Promega Corp.), $1 \mu \mathrm{l}$ of $0.2 \mathrm{mM}$ dNTP mix (Promega Corp.), $2 \mu l$ of $10 \mathrm{mM}$ forward primer, $2 \mu \mathrm{l}$ of $10 \mathrm{mM}$ reverse primer, $2.5 \mathrm{U}(0.2 \mu \mathrm{l})$ of GoTaq DNA polymerase (Promega Corp.), and $3 \mu \mathrm{l}$ of template DNA. Universal primers for $\mathrm{CR} 1, \mathrm{CR} 2$, and CR3 were used to amplify these regions (Supplementary Table S1). PCR cycling parameters, provided by McGhee and Sundin (2012), were $94^{\circ} \mathrm{C}$ for $5 \mathrm{~min}$ for initial denaturation followed by 40 cycles of $94^{\circ} \mathrm{C}$ for $30 \mathrm{~s}$, annealing at $58^{\circ} \mathrm{C}$ for CR1 and CR2 or $55^{\circ} \mathrm{C}$ for $\mathrm{CR} 3$, and extension at $72^{\circ} \mathrm{C}$ for $4 \mathrm{~min}$ for $\mathrm{CR} 1$ and $\mathrm{CR} 2$ or $45 \mathrm{~s}$ for CR3. A final extension was performed at $72^{\circ} \mathrm{C}$ for $7 \mathrm{~min}$.

Separation and visualization of PCR products was completed via gel electrophoresis using $1 \%$ agarose gels in $1 \times$ Tris-acetate-EDTA buffer (44.5 mM Tris-acetate and $1 \mathrm{mM}$ EDTA, $\mathrm{pH}$ 8.0) at $90 \mathrm{~V}$ for 60 min. PCR products were purified using a DNA Clean \& Concentrator kit (Zymo Research, Irvine, CA). Amplified and purified PCR products were sequenced at the Cornell Biotechnical Resource Center in Ithaca, NY using an ABI 3730xl capillary electrophoresis instrument (Applied Biosystems, Waltham, MA). Primer walking, with approximately four to six sequencing reactions for large PCR products obtained for spacer arrays CR1 and CR2, was completed when necessary using primers developed in this study.

Sequence analysis and CRISPR spacer array patterns. Sequencing data were assembled into complete CR1, CR2, and CR3 spacer array regions for each isolate using CLC Main Workbench (CLC Bio, Qiagen, Venlo, The Netherlands). Spacer patterns were constructed by annotating each spacer based on a comprehensive spacer key for E. amylovora provided by McGhee and Sundin (2012) (Fig. 1). Newly described spacers from this study were added to the existing key and designated a unique number. CRISPR spacer array profiles were constructed from the individual spacer array patterns of CR1, CR2, and CR3 spacer array regions (Table 1). Spacers and spacer patterns were compared between all isolates used in this study and GenBank sequencing data from previously described isolates collected from locations across the United States. These comparisons were used to identify similarities or differences between isolates. Sequences of CR1, CR2, and CR3 CRISPR spacer array regions were submitted to the National Center for Biotechnology Information database and given a reference accession number. Accession numbers are listed in Supplementary Table S2.

CRISPR spacer array profiles created for each isolate were recorded for each year of the survey and linked to global positioning system data using Google Maps (Google Inc., Mountain View, CA) 
for spatiotemporal considerations. CRISPR profiles of isolates were compared with other isolates collected at the same location if samples were collected from the same location over multiple years. Such location-specific comparisons were limited by the development of fire blight from year to year because apple producers work to avoid fire blight management failures. CRISPR spacer array profiles of SmR E. amylovora were compared with those of SmS E. amylovora isolates at corresponding collection locations and within the same county in order to explore the possibility of resistance development within New York.

To observe genotypic differences among New York isolates from differing locations and with differing streptomycin sensitivity, cluster analysis was performed on CRISPR spacer array profiles for E. amylovora isolates. CRISPR spacer content for CR1, CR2, and CR3 was concatenated and converted to a binary data set based on the presence or absence of individual spacers. A distance matrix was first created using the DISTANCE procedure of SAS (version 9.4; SAS Institute Inc. Cary, NC) using the Jaccard coefficient and, subsequently, the CLUSTER procedure of SAS (version 9.4; SAS Institute Inc.) was performed in conjunction with the TREE procedure of SAS (version 9.4; SAS Institute Inc.) to visualize the cluster analysis (Kuhfeld and Kuo 2010).

\section{Results}

CRISPR spacer array patterns and profiles. In total, $27 \mathrm{SmR}$, including the SmR E. amylovora isolates collected in 2002, and $76 \mathrm{SmS}$ E. amylovora isolates collected within 61 individual orchard sites in New York from 2011 to 2014 were evaluated for CRISPR spacer array content. These isolates represented 5 years of E. amylovora collections in New York orchards. Patterns for CRISPR spacer arrays CR1, CR2, and CR3 are diagrammed in Figure 1. Among the sequenced isolates there were $14 \mathrm{CR} 1$ patterns, $9 \mathrm{CR} 2$ patterns, and 1 CR3 pattern. Of the 14 CR 1 patterns and 9 CR 2 patterns, 10 and 4 of these patterns, respectively, had not been previously described.

CRISPR spacer array profiles created by combining the patterns of the CR1, CR2, and CR3 spacer array regions are listed for each isolate in Table 1. There were 19 distinct profiles for New York SmR and SmS E. amylovora isolates. Of these 19 profiles, only 5 profiles (4:27:38, 4:21:38, 5:27:38, 40:27:38, and 44:34:38) were shared between SmR and SmS E. amylovora isolates. Two profiles (15: 34:38 and 41:23:38) were exclusive to $\mathrm{SmR}$ E. amylovora isolates. Isolates with the CRISPR profile 41:23:38 included the two isolates discovered in 2002 (Russo et al. 2008). The remaining 12 profiles (2:22:38, 4:56:38, 4:57:38, 4:58:38, 47:27:38, 50:27:38, 42:27:38, 5:55:38, 51:27:38, 43:27:38, 53:27:38, and 52:27:38) were exclusive to SmS E. amylovora isolates (Table 1). In all, $6 \mathrm{SmR}$ E. amylovora and $50 \mathrm{SmS} \mathrm{E}$. amylovora, many from the same corresponding isolation sites, had the profile 4:27:38 (Table 1). This profile is also found in Michigan $\mathrm{SmR}$ and $\mathrm{SmS}$ E. amylovora isolates. The most common CRISPR profile found in New York E. amylovora isolates from a wide range of locations was 4:27:38.

Cluster analysis revealed that CRISPR profiles clustered into three major groups, accounting for about $68 \%$ of variance among genotypes (Fig. 2.). Group 1 contained isolates with the profiles 15:34: 38 and 44:34:38 from three orchards, which were either identical or similar, respectively, to CRISPR sequences of SmR E. amylovora isolates from the western United States (McGhee and Sundin 2012). Isolates with the profile 15:34:38 were all $\mathrm{SmR}$, while isolates with the profile 44:34:38 were both $\mathrm{SmR}$ and $\mathrm{SmS}$. SmS E. amylovora isolates from these three orchards had profiles 4:27:38, 41:23:38, 42:27:38, and 5:27:38 found in group 3 (Fig. 2). Group 2 contained isolates from seven orchards with the CRISPR profiles 2:22:38, 4:56:38, $4: 21: 38$, and 4:57:38, while group 3 contained isolates from 54 orchards with the CRISPR profiles 4:27:38, 4:58:38, 47:27:38, 50:27:38, 42:27:38, 5:27:38, 5:55:38, 51:27:38, 41:23:38, 40:27:38, 43:27:38, 53:27:38, and 52:27:38 (Fig. 2).

The geographical location of SmR E. amylovora isolates with certain CRISPR spacer profiles was tracked over several years. The two isolates NY17.1 and NY17.2 from the original introduction of SmR E. amylovora in 2002 (Russo et al. 2008) had the profile 41:23:38. This profile was observed again in isolates collected from nine
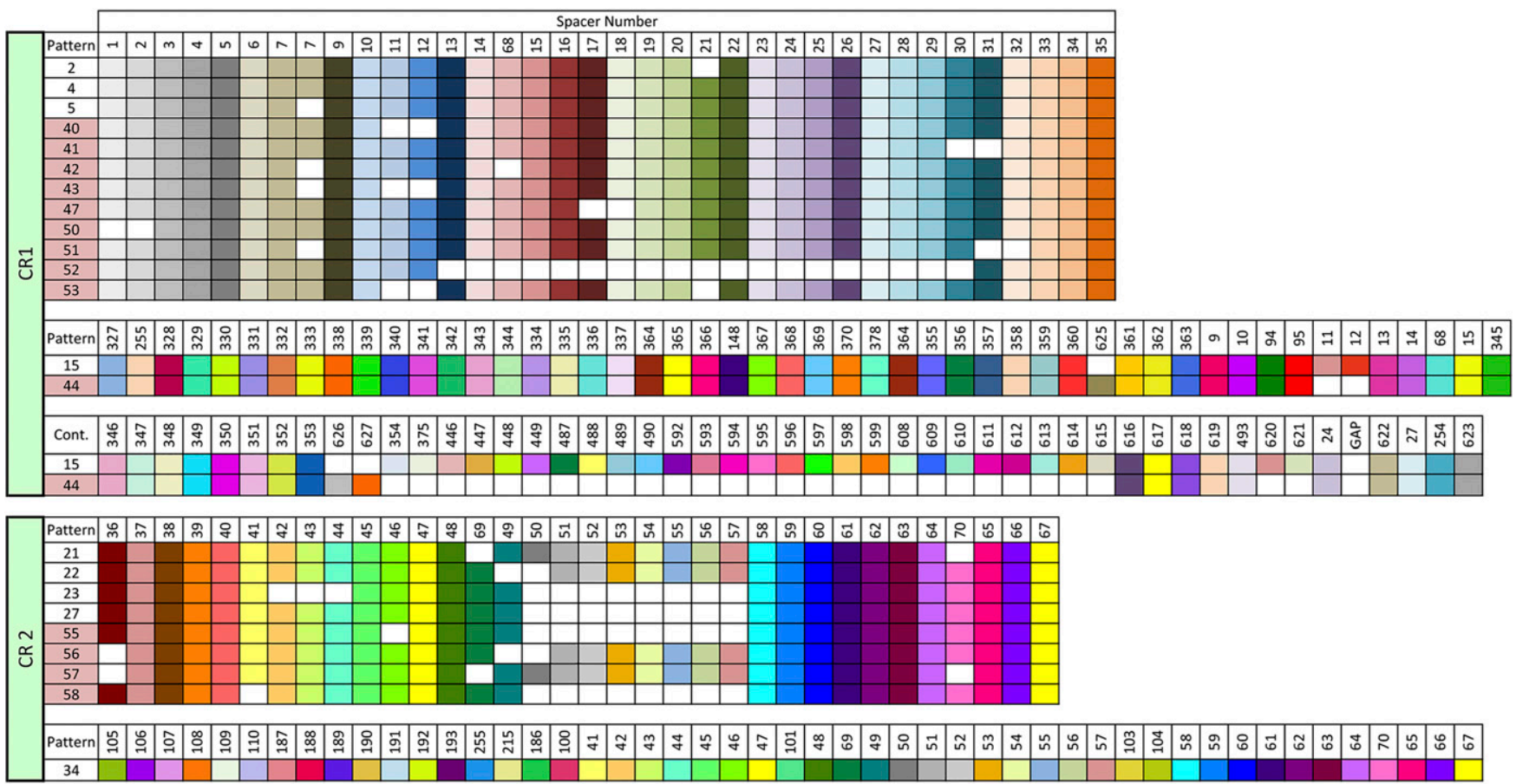

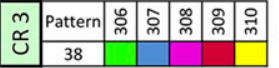

Fig. 1. Spacer content of clustered regularly interspaced short palindromic repeat arrays $C R 1, C R 2$, and $C R 3$ for all Erwinia amylovora isolates used in this study. Spacers are represented by boxes and given a number in the top row. Unique numbering is given to spacers that differ from other spacer sequences by at least 5 nucleotides. Spacers are arranged in patterns, which are given a pattern number in the left column. Pattern numbers that are shaded are newly discovered in this study, while white boxes represent patterns previously described by McGhee and Sundin (2012). GAP denotes an area of the spacer array sequence that did not contain direct repeats or spacers. 
individual orchards in four counties in 2012. SmR E. amylovora isolates with profile 4:27:38 were first observed in 2011 in one orchard and then observed again in 2013 in three orchards in three different counties. SmR E. amylovora isolates with the CRISPR profiles 5: 27:38, 15:34:38, 4:21:38, 40:27:38, and 44:34:38 were only isolated from single orchards in 1 year. Although isolates with CRISPR profiles 4:21:38, 4:27:38, and 40:27:38 were isolated from 15 orchards with fire blight outbreaks in later years, all isolates collected from these orchards were SmS (data not shown).

\section{Discussion}

CRISPR spacer array analysis has allowed New York SmR and SmS E. amylovora isolates to be grouped into 19 distinct CRISPR profiles clustered into three groups. In some cases, orchards had isolates from different groups, which could potentially indicate new introductions. The majority of SmR isolates shared the CRISPR profile 41:23:38 with the original SmR isolates NY17.1 and NY17.2 discovered in 2002 (Russo et al. 2008). Isolates with this profile were found within seven individual orchards surrounding the 2002 orchard site across the Lake Ontario region. Based on the prevalence of SmR E. amylovora isolates with the CRISPR profile 41:23:38 and the lack of SmS E. amylovora isolates with this CRISPR profile, it is possible

Table 1. Clustered regularly interspaced short palindromic repeat (CRISPR) profiles associated with streptomycin-sensitive (SmS) and streptomycin-resistant (SmR) Erwinia amylovora isolates

\begin{tabular}{|c|c|c|c|c|c|c|c|}
\hline \multirow[b]{2}{*}{ Orchard } & \multirow[b]{2}{*}{ County } & \multirow[b]{2}{*}{ Town } & \multicolumn{3}{|c|}{ CRISPR profile } & \multicolumn{2}{|c|}{$\begin{array}{l}\text { Number of } \\
\text { isolates }\end{array}$} \\
\hline & & & CR1 & CR2 & CR3 & $\mathrm{SmS}$ & $\mathrm{SmR}$ \\
\hline $\mathrm{C} 1$ & Clinton & Peru & 47 & 27 & 38 & 1 & 0 \\
\hline M1 & Monroe & Hamlin & 4 & 27 & 38 & 1 & 0 \\
\hline \multirow[t]{2}{*}{ M2 } & Monroe & Brockport & 4 & 27 & 38 & 2 & 0 \\
\hline & & & 41 & 23 & 38 & 0 & 1 \\
\hline \multirow[t]{2}{*}{ M3 } & Monroe & Hilton & 4 & 21 & 38 & 1 & 0 \\
\hline & & & 4 & 27 & 38 & 1 & 1 \\
\hline \multirow[t]{3}{*}{ N1 } & Niagara & Appleton & 4 & 27 & 38 & 1 & 0 \\
\hline & & & 41 & 23 & 38 & 0 & 1 \\
\hline & & & 53 & 27 & 38 & 1 & 0 \\
\hline $\mathrm{N} 2$ & Niagara & Wilson & 4 & 27 & 38 & 1 & 0 \\
\hline N3 & Niagara & Gasport & 4 & 27 & 38 & 1 & 0 \\
\hline $\mathrm{N} 4$ & Niagara & Burt & 4 & 57 & 38 & 1 & 0 \\
\hline N5 & Niagara & Appleton & 4 & 27 & 38 & 1 & 0 \\
\hline N6 & Niagara & Ransonville & 4 & 58 & 38 & 1 & 0 \\
\hline $\mathrm{O} 1$ & Ontario & Geneva & 53 & 27 & 38 & 1 & 0 \\
\hline \multirow[t]{2}{*}{$\mathrm{O} 2$} & Ontario & Phelps & 4 & 27 & 38 & 1 & 0 \\
\hline & & & 41 & 23 & 38 & 0 & 2 \\
\hline \multirow[t]{3}{*}{$\mathrm{O} 3$} & Ontario & Geneva & 4 & 27 & 38 & 1 & 0 \\
\hline & & & 15 & 34 & 38 & 0 & 1 \\
\hline & & & 41 & 23 & 38 & 0 & 1 \\
\hline Ora1 & Orange & Warwick & 4 & 27 & 38 & 2 & 0 \\
\hline \multirow[t]{2}{*}{ Orl1 } & Orleans & Kendall & 4 & 27 & 38 & 1 & 0 \\
\hline & & & 41 & 23 & 38 & 0 & 2 \\
\hline Orl2 & Orleans & Medina & 4 & 27 & 38 & 1 & 1 \\
\hline Orl3 & Orleans & Knowlesville & 4 & 27 & 38 & 1 & 0 \\
\hline Orl4 & Orleans & Albion & 4 & 27 & 38 & 1 & 0 \\
\hline Or15 & Orleans & Kendall & 4 & 27 & 38 & 1 & 0 \\
\hline Orl6 & Orleans & Albion & 4 & 27 & 38 & 2 & 0 \\
\hline Or17 & Orleans & Albion & 4 & 27 & 38 & 1 & 0 \\
\hline Orl8 & Orleans & Knowlesville & 4 & 27 & 38 & 1 & 0 \\
\hline Or19 & Orleans & Waterport & 4 & 27 & 38 & 1 & 0 \\
\hline Orl10 & Orleans & Knowlesville & 5 & 55 & 38 & 1 & 0 \\
\hline \multirow[t]{2}{*}{ Orl11 } & Orleans & Albion & 4 & 27 & 38 & 1 & 0 \\
\hline & & & 40 & 27 & 38 & 1 & 0 \\
\hline Orl12 & Orleans & Albion & 4 & 27 & 38 & 1 & 0 \\
\hline Orl13 & Orleans & Waterport & 4 & 27 & 38 & 1 & 0 \\
\hline Orl14 & Orleans & Lyndonville & 52 & 27 & 38 & 1 & 0 \\
\hline \multirow[t]{2}{*}{ Os1 } & Oswego & Oswego & 4 & 27 & 38 & 1 & 0 \\
\hline & & & & \multicolumn{4}{|c|}{ (continued in next column) } \\
\hline
\end{tabular}

that the neighboring orchards from which $\mathrm{SmR}$ E. amylovora isolates were first observed in 2002 is the primary source of the SmR E. amylovora found in many western New York orchards. It is possible that eradication efforts at this site were not successful in preventing the spread of these resistant strains to other orchards. Alternatively, nearby orchards may have also acquired plants from the same infected source and either effectively managed fire blight with cultural controls and growth regulators, or did not report any fire blight management failures from 2002 to 2011. The absence of SmS E. amylovora with the profile 41:23:38 suggests that these isolates did not acquire resistance within New York but, rather, SmR E. amylovora isolates were introduced into the state. However, the lack of SmS isolates collected with this CRISPR profile may be limited by the number of infected trees at the locations from which to sample, seasonal variability in the development of fire blight due to unfavorable environmental conditions, and grower efforts to aggressively eradicate fire blight and SmR E. amylovora in later years. In this capacity, isolates of E. amylovora could not be isolated in later years from many of the sites where SmR E. amylovora was discovered in 2011 to 2013. Although cultivar information from each isolate was noted, there were no relationships between SmR E. amylovora isolates with certain CRISPR profiles and specific apple cultivars (data not shown).

Table 1. (continued from preceding column)

\begin{tabular}{|c|c|c|c|c|c|c|c|}
\hline \multirow[b]{2}{*}{ Orchard } & \multirow[b]{2}{*}{ County } & \multirow[b]{2}{*}{ Town } & \multicolumn{3}{|c|}{ CRISPR profile } & \multicolumn{2}{|c|}{$\begin{array}{c}\text { Number of } \\
\text { isolates }\end{array}$} \\
\hline & & & CR1 & CR2 & $\overline{C R 3}$ & $\mathrm{SmS}$ & SmR \\
\hline$\overline{\mathrm{S} 1}$ & Suffolk & Mattituck & 2 & 22 & 38 & 1 & 0 \\
\hline $\mathrm{S} 2$ & Suffolk & Wading River & 4 & 21 & 38 & 1 & 0 \\
\hline S3 & Suffolk & Calverton & 4 & 21 & 38 & 1 & 0 \\
\hline $\mathrm{T} 1$ & Tompkins & Lansing & 44 & 34 & 38 & 1 & 2 \\
\hline $\mathrm{U} 1$ & Ulster & Marlboro & 2 & 22 & 38 & 2 & 0 \\
\hline W0 & Wayne & Sodus & 41 & 23 & 38 & 0 & 2 \\
\hline \multirow[t]{2}{*}{ W1 } & Wayne & Huron & 4 & 27 & 38 & 2 & 2 \\
\hline & & & 41 & 23 & 38 & 0 & 1 \\
\hline W2 & Wayne & Marion & 4 & 27 & 38 & 1 & 0 \\
\hline \multirow[t]{2}{*}{ W3 } & Wayne & Williamson & 4 & 27 & 38 & 2 & 0 \\
\hline & & & 41 & 23 & 38 & 0 & 3 \\
\hline \multirow[t]{5}{*}{ W4 } & Wayne & Wolcott & 4 & 27 & 38 & 1 & 0 \\
\hline & & & 5 & 27 & 38 & 0 & 1 \\
\hline & & & 15 & 34 & 38 & 0 & 1 \\
\hline & & & 41 & 23 & 38 & 0 & 1 \\
\hline & & & 42 & 27 & 38 & 1 & 0 \\
\hline \multirow[t]{2}{*}{ W5 } & Wayne & Macedon & 4 & 27 & 38 & 3 & 0 \\
\hline & & & 41 & 23 & 38 & 0 & 1 \\
\hline \multirow[t]{2}{*}{ W6 } & Wayne & Williamson & 40 & 27 & 38 & 0 & 1 \\
\hline & & & 43 & 27 & 38 & 1 & 0 \\
\hline W7 & Wayne & Wolcott & 4 & 27 & 38 & 2 & 1 \\
\hline W8 & Wayne & Sodus & 4 & 21 & 38 & 1 & 1 \\
\hline W9 & Wayne & Williamson & 50 & 27 & 38 & 1 & 0 \\
\hline W10 & Wayne & Williamson & 40 & 27 & 38 & 1 & 0 \\
\hline W11 & Wayne & North Rose & 51 & 27 & 38 & 2 & 0 \\
\hline W12 & Wayne & Williamson & 5 & 27 & 38 & 1 & 0 \\
\hline W13 & Wayne & Sodus & 4 & 27 & 38 & 2 & 0 \\
\hline \multirow[t]{2}{*}{ W14 } & Wayne & Williamson & 4 & 27 & 38 & 1 & 0 \\
\hline & & & 40 & 27 & 38 & 1 & 0 \\
\hline W15 & Wayne & North Rose & 4 & 27 & 38 & 1 & 0 \\
\hline W16 & Wayne & Williamson & 4 & 27 & 38 & 1 & 0 \\
\hline W17 & Wayne & Williamson & 4 & 27 & 38 & 1 & 0 \\
\hline W18 & Wayne & Sodus & 4 & 27 & 38 & 1 & 0 \\
\hline W19 & Wayne & Williamson & 4 & 27 & 38 & 1 & 0 \\
\hline W20 & Wayne & Wolcott & 4 & 27 & 38 & 1 & 0 \\
\hline W21 & Wayne & Alton & 4 & 27 & 38 & 1 & 0 \\
\hline W22 & Wayne & Wolcott & 4 & 27 & 38 & 1 & 0 \\
\hline W23 & Wayne & Sodus & 4 & 27 & 38 & 1 & 0 \\
\hline W24 & Wayne & Sodus & 4 & 27 & 38 & 1 & 0 \\
\hline W25 & Wayne & Williamson & 40 & 27 & 38 & 1 & 0 \\
\hline Y1 & Yates & Penn Yan & 4 & 56 & 38 & 1 & 0 \\
\hline
\end{tabular}


This is not surprising given the rarity of SmR E. amylovora in New York orchards and the infrequency of fire blight outbreaks from season to season.

The discovery of six additional CRISPR profiles (15:34:38, 44:34: 38, 4:21:38, 4:27:38, 5:27:38, and 40:27:38) in SmR E. amylovora isolates provides evidence that events other than the 2002 occurrence may have led to the development of streptomycin resistance in New York. The presence of isolates in New York with CRISPR profile 15: $34: 38$, which is identical to those of western U.S. isolates, possibly suggests an introduction event. The profile 15:34:38 is associated with isolates from the western United States with the rpsL mutation (McGhee and Sundin 2012). Two isolates in this study from two different commercial orchards were found to have the CRISPR profile 15:34:38 and a point mutation at codon 43 of the rps $L$ gene. The presence of this CRISPR profile within two geographically isolated orchards in Wayne and Ontario Counties and the lack of SmS E. amylovora isolates with a similar CRISPR profile suggest multiple introductions of SmR E. amylovora from western sources. An earlier introduction with subsequent dispersal is less likely given that the two orchards are further apart $(>8.6 \mathrm{~km})$ than the limit for local environmental dispersal (van der Zwet et al. 2012). Moreover, the two growers with this isolate have never shared material or had reason to do so (K. D. Cox, personal communication).

Although recent introduction events may explain the presence of SmR E. amylovora in some orchards, some CRISPR profiling data also suggest that resistance may be developing within the state. Of $76 \mathrm{SmS}$ E. amylovora isolates from 40 different orchards in seven counties (Monroe, Niagara, Ontario, Orange, Orleans, Oswego, and Wayne), 50 had the CRISPR profile 4:27:38 (Table 1). Interestingly, this profile was also found in six SmR E. amylovora isolates within four orchards in three counties (Monroe, Orleans, and Wayne). Isolates of $\mathrm{SmS}$ and $\mathrm{SmR}$ E. amylovora with this profile were also recovered from apple orchards from Michigan (McGhee and Sundin 2012). The fact that E. amylovora isolates with the same CRISPR profile and both SmS and SmR phenotypes are present in the same orchard suggests that streptomycin resistance may have developed within the local populations. However, the fact that E. amylovora isolates with the same CRISPR profile and both SmS and SmR phenotypes are present in multiple orchards in different states would also suggest that they were introduced together from Michigan into New York or vice versa. E. amylovora isolates with CRISPR profiles 4: 21:38 (also found in Michigan; McGhee and Sundin 2012) and 44: 34:38, with both SmR and SmS phenotypes, were also recovered from the same orchards, serving as evidence to further support the theory of resistance development within New York. Interestingly, the CRISPR profile 44:34:38 is similar to the profile 15:34:38 (Fig. 2) and, therefore, similar to western U.S. isolates (McGhee and Sundin, 2012). This is concerning because it may suggest that western U.S. CRISPR profiles may not be confined to the west coast and that New York is possibly the origin of these isolates. This would not be entirely surprising, given that E. amylovora was first discovered in the Hudson Valley region of New York in 1794 (Denning 1794). It is possible that these seemingly introduction events could actually be reintroduction events into the state, given the rarity of $\mathrm{SmS} \mathrm{E}$. amylovora isolates with CRISPR profiles similar to those of isolates collected in the western United States.

The evidence from the present study suggesting multiple introductions or reintroductions of SmR E. amylovora into New York may highlight the inadequacies of pathogen screening of plant material imported into the state. Commercial orchards in New York rely heavily on trees and budwood from both local and out-of-state sources, and the majority of sources are located in regions with a history of SmR E. amylovora. Nurseries strive to maintain healthy plantings that are regularly scouted for diseased plants; however, it is known that E. amylovora may survive asymptomatically in young trees (Keil and van der Zwet 1972; McManus and Jones 1994; Smith 2002). Asymptomatic trees could serve as a reservoir for antibiotic-resistant strains that produce disease in established orchards. Screening asymptomatic trees for E. amylovora ( $\mathrm{SmS}$ or $\mathrm{SmR})$ strains is not commonplace in nurseries but may help mitigate the spread of these strains in later years.

The fear of local resistance development has largely influenced New York production guidelines outlining the use of streptomycin

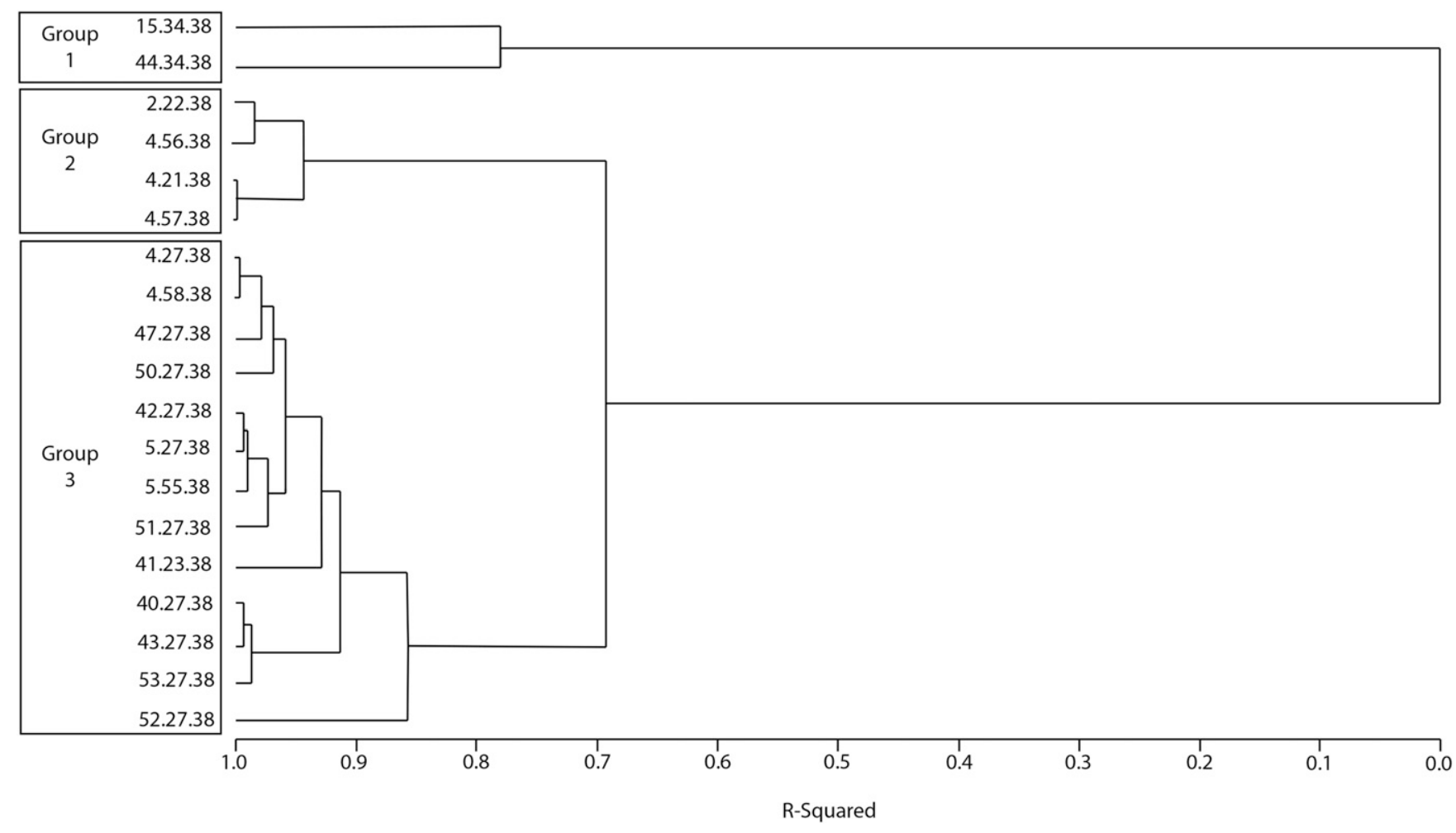

Fig. 2. Distance matrix constructed based on cluster analysis of concatenated spacers for clustered regularly interspaced short palindromic repeat (CRISPR) arrays CR1, CR2, and $\mathrm{CR} 3$ for all isolates used in this study. Distances are represented as $R^{2}$ values on the $\mathrm{x}$-axis. CRISPR profiles were placed into three groups based on divergence, accounting for $68 \%$ of variability among profiles. 
to manage fire blight (Agnello et al. 2015), and may have contributed to relatively few putative cases of local selection as presented in the current study. It is recommended that streptomycin should only be applied during bloom and after significant trauma events that put trees at high risk for infection in order to reduce selection pressure for resistant strains. Alternative controls, such as the biostatic antibiotic oxytetracycline, growth regulator prohexadionecalcium, and copper products, although they do not provide control comparable with streptomycin, are recommended in concert with streptomycin to manage fire blight and to mitigate resistance development within individual orchards (Cox et al. 2013; Sundin and Ehret 2010; Yoder et al. 2010). Kasugamycin is a highly effective antibiotic for fire blight management with no known resistance in $E$. amylovora in Michigan, where streptomycin resistance is a concern (McGhee and Sundin 2011; Sundin and Ehret 2012). However, this antibiotic has just become available for use in New York and is relatively expensive in comparison with streptomycin, making kasugamycin a less cost-effective option for growers, especially during years when environmental conditions are conducive for severe fire blight epidemics.

The streptomycin resistance development in populations of E. amylovora has become an increasingly important issue with New York apple growers over the past decade. Isolates of SmR E. amylovora have been found in orchards in all of the major apple-growing counties in western New York. CRISPR spacer array analysis was used to better understand isolate diversity and to infer possible isolate origins. Our results suggest introduction events or reintroductions may be the primary source of $\mathrm{SmR}$ E. amylovora in New York. However, in cases where SmS and SmR isolates share identical CRISPR profiles, local selection for streptomycin resistance may have occurred. Were we able to apply this technique from 2002 to 2011 on local populations regardless of fire blight development, we would have a better understanding of the origin. In this capacity, we are prepared to understand the origin of $\operatorname{SmR}$ E. amylovora in eastern New York, because there has been considerable surveying of the eastern New York apple orchards where streptomycin resistance is absent (Tancos et al. 2016). Continued CRISPR spacer array profiling of E. amylovora in commercial apple orchards will further elucidate factors that contribute to streptomycin resistance development within individual orchards and help mitigate the spread of resistance in surrounding regions.

\section{Acknowledgments}

This research was supported, in part, by funding from state, federal, and institutional funds appropriated to the New York State Agricultural Experiment Station, New York State IPM, New York State Department of Agriculture \& Markets-Specialty Crop Block Grant Program, and the Apple Research and Development Program. We thank D. Breth, S. Villani, and S. Kuehne for their technical support.

\section{Literature Cited}

Agnello, A. M., Landers, A. J., Rosenberger, D., Cox, K. D., Robinson, T. L., Carroll, J. E., Breth, D., Kain, D., Bellinder, R., Stiles, W., Cheng, L., Hoying, S., and Curtis, P. 2015. Pest Management Guidelines for Commercial TreeFruit Production 2015. Cornell Cooperative Extension, New York State Agricultural Experiment Station, Geneva.

Almendros, C., Francisco, J. M. M., Díez-Villaseñor, C., Guzmán, N. M., and García-Martínez, J.. 2014. CRISPR-Cas functional module exchange in Escherichia coli. Online publication. mBio 5:e00767-13.

Barros, M. P. S., França, C. T., Lins, R. H. F. B., Santos, M. D. V., Silva, E. J., Oliveira, M. B. M., Silveira-Filho, V. M., Rezende, A. M., Balbino, V. Q., and Leal-Balbino, T. C. 2014. Dynamics of CRISPR loci in microevolutionary process of Yersinia pestis strains. Online publication. PLoS One 9: e108353.

Bertani, G. 1952. Studies on lysogenesis. I. The mode of phage liberation by lysogenic Escherichia coli. J. Bacteriol. 62:293-300.

Burr, T. J., Norelli, J. L., Katz, B., Wilcox, W. F., and Hoying, S. A. 1988. Streptomycin resistance of Pseudomonas syringae pv. papulans in apple orchards and its association with a conjugative plasmid. Phytopathology 78:410-413.

Burr, T. J., Norelli, J. L., Reid, C. L., Capron, L. K., Nelson, L. S., Aldwinckle, H. S., and Wilcox, W. F. 1993. Streptomycin-resistant bacteria associated with fire blight infections. Plant Dis. 77:63-66.

Chiou, C. S., and Jones, A. L. 1993. Nucleotide-sequence analysis of a transposon (Tn5393) carrying streptomycin resistance genes in Erwinia amylovora and other gram-negative bacteria. J. Bacteriol. 175:732-740.
Chiou, C. S., and Jones, A. L. 1995a. Expression and identification of the strA-strB gene pair from streptomycin-resistant Erwinia amylovora. Gene 152:47-51.

Chiou, C. S., and Jones, A. L. 1995b. Molecular analysis of high-level streptomycin resistance in Erwinia amylovora. Phytopathology 85:324-328.

Cox, K. D., Aldwinckle, H. S., Villani, S. M., and Bekoscke, K. A. 2013. Evaluation of bactericide programs for the management of fire blight on 'Idared' apples in NY, 2012. Online publication. Plant Dis. Manage. Rep. 7:PF001.

Coyier, D. L., and Covey, R. P. 1975. Tolerance of Erwinia amylovora to streptomycin sulfate in Oregon and Washington. Plant Dis. Rep. 59:849-852.

Crosse, J. E., and Goodman, R. N. 1973. A selective medium for and a definitive colony characteristic of Erwinia Amylovora. Phytopathology 63:1425-1426.

Denning, W. 1794. On the decay of apple trees. N.Y. Soc. Promot. Agric. Arts Manuf. Trans. 2:219-222.

Förster, H., McGhee, G. C., Sundin, G. W., and Adaskaveg, J. E. 2015. Characterization of streptomycin resistance in isolates of Erwinia amylovora in California. Phytopathology 105:1302-1310.

Horvath, P., Romero, D. A., Coûté-Monvoisin, A., Richards, M., Deveau, H., Moineau, S., Boyaval, P., Fremaux, C., and Barrangou, R. 2008. Diversity, activity, and evolution of CRISPR loci in Streptococcus thermophilus. J. Bacteriol. 190:1401-1412.

Jock, S., Donat, V., Lopez, M. M., Bazzi, C., and Geider, K. 2002. Following spread of fire blight in western, central, and southern Europe by molecular differentiation of Erwinia amylovora strains with PFGE analysis. Environ. Microbiol. 4:106-114.

Johnson, K. B., Sawyer, T. L., Stockwell, V. O., and Temple, T. N. 2009 Implications of pathogenesis by Erwinia amylovora on rosaceous stigmas to biological control of fire blight. Phytopathology 99:128-138.

Keil, H. L., and van der Zwet, T. 1972. Recovery of Erwinia amylovora from symptomless stems and shoots of Jonathan apple and Bartlett pear trees. Phytopathology 62:39-42.

Kim, W. S., and Geider, K. 1999. Analysis of variable short-sequence DNA repeats on the $29 \mathrm{~kb}$ plasmid of Erwinia amylovora strains. Eur. J. Plant Pathol. 105 703-713.

Kuhfeld, W. F., and Kuo, A. 2010. The DISTANCE procedure. Pages 2041-2050 in: SAS/STAT 9.22 User's Guide. T. Arnold and A. Jones, eds. SAS Institute Inc., Cary, NC.

McGhee, G. C., and Sundin, G. W. 2011. Evaluation of kasugamycin for fire blight management, effect on nontarget bacteria, and assessment of kasugamycin resistance potential in Erwinia amylovora. Phytopathology 101:192-204.

McGhee, G. C., and Sundin, G. W. 2012. Erwinia amylovora CRISPR elements provide new tools for evaluating strain diversity and for microbial source tracking. PLoS One 7:e41706.

McManus, P. S., and Jones, A. L. 1994. Epidemiology and genetic analysis of streptomycin-resistant Erwinia amylovora from Michigan and evaluation of oxytetracycline for control. Phytopathology 84:627-633.

McManus, P. S., Stockwell, V. O., Sundin, G. W., and Jones, A. L. 2002. Antibiotic use in plant agriculture. Annu. Rev. Phytopathol. 40:443-465.

Miller, T. D., and Schroth, M. N. 1972. Monitoring the epiphytic population of Erwinia amylovora on pear with a selective medium. Phytopathology 62: 1175-1182.

Moller, W., Schroth, M. N., and Thompson, S. V. 1981. The scenario of fire blight and streptomycin resistance. Plant Dis. 65:563-568.

Momol, M. T., Momol, E. A., Lamboy, W. F., Norelli, J. L., Beer, S. V., and Aldwinckle, H. S. 1997. Characterization of Erwinia amylovora isolates using random amplified polymorphic DNA fragments (RAPDs). J. Appl. Microbiol. 82:389-398.

Norelli, J. L., Jones, A. L., and Aldwinckle, H. S. 2003. Fire blight management in the twenty-first century: Using new technologies that enhance host resistance in apple. Plant Dis. 87:756-765.

Palmer, E. L., Teviotdale, B. L., and Jones, A. L. 1997. A relative of the broad host range plasmid RSF1010 detected in Erwinia amylovora. Appl. Environ. Microbiol. 63:4604-4607.

Rezzonico, F., Smits, T. H. M., and Duffy, B. 2011. Diversity, evolution, and functionality of clustered regularly interspaced short palindromic repeat (CRISPR) regions in the fire blight pathogen Erwinia amylovora. Appl. Environ. Microbiol. 77:3819-3829.

Russo, N. L., Burr, T. J., Breth, D. I., and Aldwinckle, H. S. 2008. Isolation of streptomycin-resistant isolates of Erwinia amylovora in New York. Plant Dis. 92:714-718.

Sebaihia, M., Bocsancy, A. M., Biehl, B. S., Quail, M. A., and Perna, N. T. 2010 Complete genome sequence of the plant pathogen Erwinia amylovora strain ATCC 49946. J. Bacteriol. 192:2020-2021.

Shariat, N., Sandt, C. H., DiMarzio, M. J., Barrangou, R., and Dudley, E. G. 2013. CRISPR-MVLST subtyping of Salmonella enterica subsp. enterica serovars Typhimurium and Heidelberg and application in identifying outbreak isolates. BMC Microbiol. 13:254-271.

Smith, T. J. 2002. The three-season evolution of a fire blight outbreak in a nursery using an asymptomatic apple bud wood source contaminated with Erwinia amylovora. Acta Hortic. 590:109-113.

Smits, T. H. M., Rezzonico, F., Kamber, T., Blom, J., and Goesmann, A. 2010 Complete genome sequence of the fire blight pathogen Erwinia amylovora CFBP 1430 and comparison to other Erwinia spp. Mol. Plant-Microbe Interact. 23:384-393. 
Sundin, G. W. 2014. Fire blight. Pages 87-89 in: Compendium of Apple and Pear Diseases and Pests, 2nd ed. Sutton, T. B., Aldwinckle, H. S., Agnello, A. M., and Walgenbach, J. F., eds. American Phytopathological Society, St. Paul, MN.

Sundin, G. W., and Ehret, G. R. 2010. Fire blight control on Jonathan apple with antibiotics in 2009. Online publication. Plant Dis. Manage. Rep. 4:PF006.

Sundin, G. W., and Ehret, G. R. 2012. Fire blight control on Jonathan apple with kasumin in 2011. Online publication. Plant Dis. Manage. Rep. 6:PF004.

Tancos, K. A., Villani, S. M., Borejza-Wysocka, E., Kuehne, S., Breth, D., Aldwinckle, H. S., Carol, J., and Cox, K. D. 2016. Prevalence of streptomycinresistant Erwinia amylovora in New York apple orchards. Plant Dis. 100:802-809. van der Zwet, T. 1969. Study of fire blight cankers and associated bacteria in pear. Phytopathology 59:607-613.

van der Zwet, T., Orolaza-Halbrendt, N., and Zeller, W. 2012. Fire Blight History,

Biology, and Management. American Phytopathological Society, St. Paul, MN.

Vanneste, J. L., ed. 2000. Epidemiology of Fire Blight. Pages 9-36 in: Fire Blight: The Disease and Its Causative Agent, Erwinia amylovora. CABI Publishing, Oxon, UK.

Yoder, K. S., Cochran, A. E., II, Royston, W. S., Jr., and Kilmer, S. W. 2010. Fire blight blossom blight suppression on Idared apple, 2009. Online publication. Plant Dis. Manage. Rep. 4:PF023. 